\title{
Increasing risks for emerging infectious diseases within a rapidly changing High Asia
}

\author{
Charudutt Mishra, Gustaf Samelius, Munib Khanyari, \\ Prashanth Nuggehalli Srinivas, Matthew Low, Carol Esson, \\ Suri Venkatachalam, Örjan Johansson (1)
}

Received: 20 January 2021 / Revised: 24 May 2021 / Accepted: 29 June 2021 / Published online: 22 July 2021

\begin{abstract}
The cold and arid mountains and plateaus of High Asia, inhabited by a relatively sparse human population, a high density of livestock, and wildlife such as the iconic snow leopard Panthera uncia, are usually considered low risk for disease outbreaks. However, based on current knowledge about drivers of disease emergence, we show that High Asia is rapidly developing conditions that favor increased emergence of infectious diseases and zoonoses. This is because of the existing prevalence of potentially serious pathogens in the system; intensifying environmental degradation; rapid changes in local ecological, socio-ecological, and socio-economic factors; and global risk intensifiers such as climate change and globalization. To better understand and manage the risks posed by diseases to humans, livestock, and wildlife, there is an urgent need for establishing a disease surveillance system and improving human and animal health care. Public health must be integrated with conservation programs, more ecologically sustainable development efforts and long-term disease surveillance.
\end{abstract}

Keywords Mountains · One Health · Pandemics .

Panthera uncia $\cdot$ Snow leopard $\cdot$ Zoonoses

\section{GLOBALLY INTENSIFYING RISK OF DISEASE EMERGENCE}

Despite more than a century of progress in disease control, emerging infectious diseases (EIDs) are a growing problem for humans, wildlife, and domesticated species (Daszak

Supplementary Information The online version contains supplementary material available at https://doi.org/10.1007/s13280021-01599-7. et al. 2000). An estimated $75 \%$ of all EIDs are zoonotic, i.e., transmitted to humans from animals (Jones et al. 2008). They include recent coronavirus outbreaks in humans such as SARS and COVID-19, as well as other well-known diseases in human history including Ebola, HIV/AIDS, avian influenza, Lyme disease, and bubonic plague (Fig. 1). In addition to the obvious seriousness of many EIDs and the need to control outbreaks, their increasing global frequency (Allen et al. 2017; Fig. 1; Table S1) points to causative agents that are related to anthropogenic disturbance of ecosystems, biodiversity loss, and changes in the way people and animals interact (Daszak et al. 2000; Jones et al. 2008; Keesing et al. 2010). Consequently, increasing disease outbreaks could be expected in populations and regions that have previously been considered at low risk, especially as traditional societal structures, modes of agriculture, and natural environmental processes are disrupted (Lindahl and Grace 2015).

Several characteristics of globalization are linked to incidences of EIDs: (i) a highly integrated global economy leading to unprecedented movement of people, animals, and goods - and, thereby, pathogens - between regions, (ii) ecological disruption and habitat fragmentation that increase contact between people, wildlife, and domestic species, and (iii) general characteristics of development such as biotic homogenization that reduces ecosystem resilience, and pesticide and antibiotic use, which can compromise immune responses and promote the emergence of resistant pathogens (Jones et al. 2008; Karesh et al. 2012; Kilpatrick and Randolph 2012). Additional factors that further increase the risk of disease transmission between animals and people include poaching, trade in wildlife (Rosen and Smith 2010; $\mathrm{Li}$ and $\mathrm{Lu}$ 2014), consumption of wildlife, and the use of wildlife in traditional medicine (Mainka and Mills 1995; Graham-Rowe 2011). 


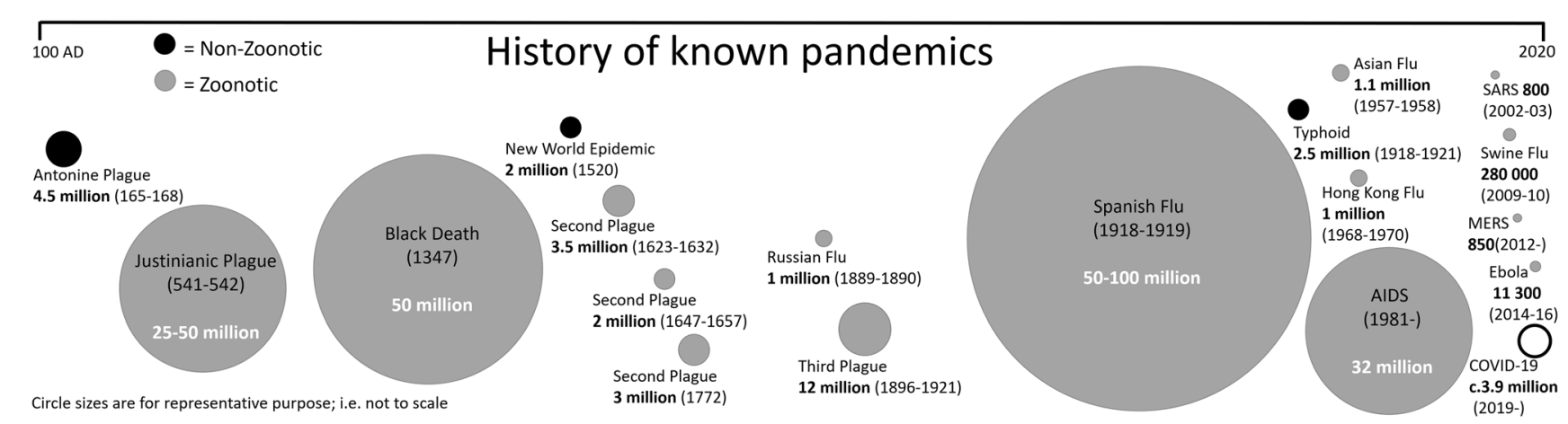

Fig. 1 Known historical zoonotic (gray) and non-zoonotic (black) pandemics and associated human fatalities. The ongoing COVID-19 pandemic (shown as open circle) is thought to be of zoonotic origin. See Table S1 for details

Thus, in areas undergoing significant changes in the frequency and type of human-animal interactions, monitoring disease transmission dynamics becomes critical for human health and welfare, and for the protection of wildlife populations and domestic livestock.

Current forecast modeling indicates South and South East Asia, Central Europe, sub-Saharan Africa, Central America, and parts of South America as being at high risk of zoonotic outbreaks and EIDs (Jones et al. 2008; Allen et al. 2017). Naturally, these forecasts are based on past spillovers and outbreaks (Jones et al. 2008). Changing ecological and socio-economic conditions in areas previously considered as relatively 'low risk,' however, could tip the balance towards a higher risk category of EIDs. One such area is the contiguous region formed by the great mountain ranges, plateaus, and intersecting steppe and valleys of Asia, characterized primarily by the Central Asian dry alpine ecosystems: hereafter High Asia (Fig. 2, Table S2). High Asia is composed of $\sim 6.4$ million square kilometers and 44 ecoregions (Olson et al. 2001), and includes the Qinghai-Tibetan Plateau and parts of the great mountain ranges of the Himalayas, Pamirs, Karakoram, Tien Shan, and Altai (Table S2). Compared to tropical and temperate systems, High Asia has seen relatively little research on EIDs and zoonotic diseases (Saker et al. 2004; Allen et al. 2017). Here, we put forward the case that High Asia is rapidly developing conditions for increased risk of disease outbreaks in both human and animal populations. We collate evidence for the prevalence of various pathogens in this region and show how multiple ecological, socio-ecological, and socio-economic factors in High Asia may be interacting with climate change and globalization to create higher risk conditions for EIDs and zoonotic outbreaks compared to what current forecast modeling suggests (Fig. 3). We define High Asia to specifically include the distribution range of the apex mountain predator, the snow leopard(Panthera uncia), and the intervening regions connecting these mountains that are ecologically and climatically similar. We focus on the snow leopard range area because it typifies the humanlivestock-wildlife relationships in this region, it is undergoing dramatic changes that we argue increase EID risk, and because of its importance for local cultural values and a globally significant wildlife conservation program. To define this region, we used the global ecoregion files for High Asia (published in Olson et al. 2001) and overlaid the current snow leopard distribution (Suryawanshi et al. 2019) using QGIS 2.18. Ecoregions coinciding with snow leopard distribution were included, as were interconnecting ecoregions that were identified by their sharing a border with at least one snow leopard ecoregion (these included mountainous ecoregions like intermontane steppe, mountain conifer forests, alpine meadows, and in limited cases non-mountainous ecoregions like desert steppes).

\section{FACTORS DISPOSING HIGH ASIA TO POTENTIAL EIDS AND ZOONOSES OUTBREAKS}

We consider the following local and global factors as likely to increase the risk of disease outbreaks in High Asia (Table 1; Fig. 3).

\section{Local ecological factors}

It is generally assumed that the cold and dry high-altitude landscapes of High Asia have lower abundance and richness of pathogens than the warmer lower elevations (Ostrowski and Gilbert 2016). However, the relative importance of pathogen abundance to the emergence of EIDs, compared to other risk factors, is largely unknown. It is also possible that lower intrinsic levels of immunity in animal populations because of lower rates of pathogen exposure or co-evolution of host-pathogen relationships compared to the tropics could render High Asian landscapes vulnerable to EIDs (Ostrowski and Gilbert 2016). 




Fig. 2 Map of High Asia (gray) including the estimated global range of the snow leopard (striped)

Recent studies of prominent wild animal taxa in High Asia, especially mammals, detail behavioral characteristics that could increase their disease exposure beyond what might be expected from the traditional view of these species (Table 1). A large proportion of High Asian mountains represent the global range of the snow leopard, a top predator and flagship species for biodiversity conservation (Fig. 2). Snow leopards occur at relatively low densities compared to other large felids (Karanth et al. 2004; Suryawanshi et al. 2019), where low densities are thought to limit the possibilities of encountering or spreading pathogens. However, snow leopards have been shown to have much larger home ranges (Johansson et al. 2016) and extensive movement behaviors (e.g., between mountain ranges [Johansson et al. 2020a]) than previously reported, increasing their chances of encountering and spreading disease within and across mountain ranges and international borders. Despite the belief that snow leopards are solitary outside mating (Fox and Chundawat 2016), individuals frequently interact, with adult males and females sometimes sharing kills and traveling together, as do females and their adult progeny (Johansson unpublished). Adults also frequently kill and interact with wild and domestic ungulate species (Johansson et al. 2015). From the perspective of snow leopard conservation, their population is likely to be relatively sensitive to disease impacts on mortality because of their slow reproductive rate related to late age at first breeding (3-4 years) and long inter-birth interval (minimum 24 months) when compared to other large felids (Johansson et al. 2020a).

The two most important prey species of the snow leopard, ibex (Capra sibirica) and blue sheep (Pseudois nayaur), show typically gregarious social behavior, along with seasonally compromised body condition due to strong seasonality and/or resource competition with sympatric livestock; factors important in regulating and spreading pathogens (Mishra et al. 2004; Ostrowski and Gilbert 2016). In addition, phylogenetic, dietary, and habitat similarities between wild ungulates and domestic livestock in this region can facilitate pathogen transfer between these groups. This has serious implications for disease risk, not only in wild and domestic animals, but also in the exposure risk of humans to these pathogens (Wolfe et al. 2007; Walker et al. 2017). Smaller species such as rodents and lagomorphs are known to carry over 60 zoonotic pathogens that can have serious effects on human and animal health (e.g., bubonic plague [Meerburg et al. 2009], Table 1). Rodents and lagomorphs are prey species of snow leopards (e.g., marmots Marmota spp. and hares Lepus spp. 


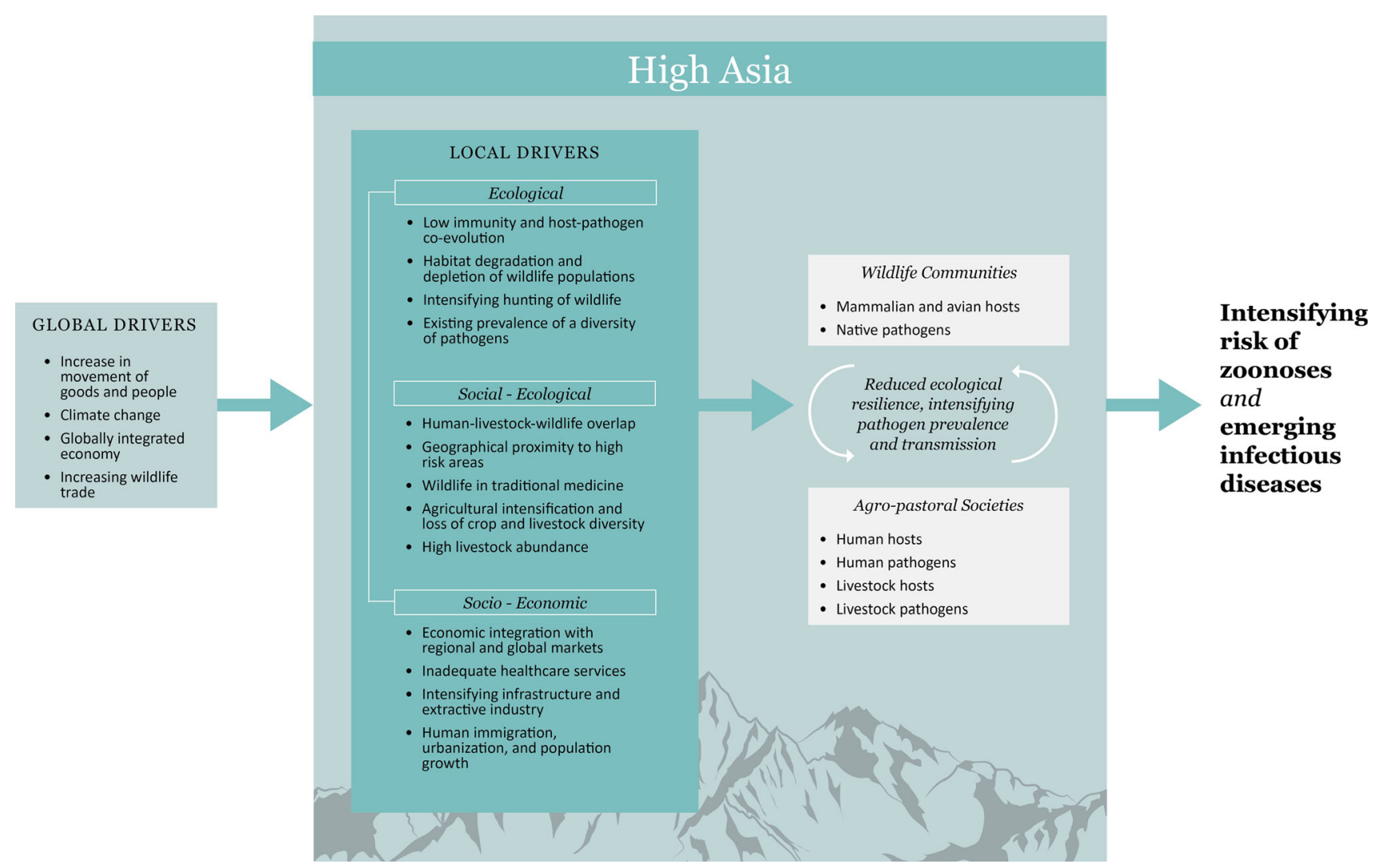

Fig. 3 Schematic diagram illustrating the increasing risk of emerging infectious diseases and zoonoses due to changes in climate and socioecological dynamics in High Asia

[Jumabay-Uulu et al. 2013]) and smaller rodents that live in close proximity to people and livestock in this region.

Bird migration is one risk factor contributing to the global spread of EIDs (Altizer et al. 2011; Reed et al. 2003). High Asia hosts breeding ground for a large number of birds, of which many are migratory (Prins and Namgail 2017). Two of the world's eight main flyways for migratory birds, the Central Asia flyway and the East Africa West Asia flyway, cross High Asia (Olsen et al. 2006). Migratory birds traveling along these corridors move from areas densely populated by people and livestock in SouthWest Africa and Southern India, respectively, towards the northernmost part of Asia, thereby potentially transferring diseases between these populations. These migratory birds use High Asia stopover sites between their breeding and wintering areas, resulting in high seasonal bird concentrations at local water sources that are also used by resident wildlife, livestock, and local people (Krauss et al. 2010; Altizer et al. 2011).

\section{Local social-ecological factors}

Human density in High Asia is relatively low, suggesting low risks of zoonotic EIDs. However, High Asian landscapes are used extensively for livestock production, and represent one of the largest rangeland systems in the world (Berger et al. 2013). The majority of people are agropastoralists and live in close proximity to livestock and wildlife (Mishra et al. 2003a, 2010), creating conditions for zoonotic spread; the abundance of livestock in this region is very high (Mishra et al. 2001; Berger et al. 2013); and people and their livestock migrate seasonally in many areas (Mijiddorj et al. 2018). These factors create a close connectivity between humans, livestock, and wildlife and their seasonal movements and interactions create a regional connectivity: key ingredients for the emergence and spread of disease (Daszak et al. 2000). Additionally, there is a considerable influx and egress of people through rapidly emerging tourism and other business and livelihood opportunities in High Asia (Mavroidi 2008; Mijiddorj et al. 2019). There is also a high dependence on traditional medicinal systems, many of which have a strong tradition of using body parts of wild species (Byard 2016; Negi and Palyal 2017), with markets where wildlife and medicines are traded in some parts of High Asia (Zhang et al. 2008).

Poaching and the trade of wildlife (both legal and illegal) is increasing in High Asia ( $\mathrm{Li}$ and $\mathrm{Lu}$ 2014; Nowell et al. 2016) resulting in wildlife populations that are under 
Table 1 Factors that reduce or increase the risk of transmission of emerging infectious diseases and zoonoses in snow leopard landscapes

\begin{tabular}{|c|c|c|c|}
\hline Local factor & Lowering the risk & Intensifying the risk & References \\
\hline \multicolumn{4}{|l|}{ Ecological factors } \\
\hline \multirow[t]{2}{*}{$\begin{array}{l}\text { Environmental } \\
\text { conditions }\end{array}$} & $\begin{array}{l}\text { Low temperatures, } \\
\text { strong seasonality }\end{array}$ & Global warming & Li et al. (2016) \\
\hline & Dry environment & Increasing precipitation and glacial melt & Turco et al. (2015) \\
\hline Pathogens & $\begin{array}{l}\text { Lower pathogen } \\
\text { abundance }\end{array}$ & Low rates of immunity against pathogens & $\begin{array}{l}\text { Ostrowski and Gilbert } \\
\text { (2016) }\end{array}$ \\
\hline \multirow[t]{2}{*}{ Human population } & $\begin{array}{l}\text { Relatively low human } \\
\text { density }\end{array}$ & Seasonal migration of humans and their livestock & Mishra et al. (2003b) \\
\hline & & Transition towards sedentarization & (Mishra et al. 2010) \\
\hline \multirow[t]{2}{*}{ Snow leopard } & Low density & Large home ranges and movement distances & Johansson et al. (2016) \\
\hline & $\begin{array}{l}\text { High dependence on } \\
\text { wild ungulates }\end{array}$ & Predation on livestock and retaliatory killing & Mishra et al. (2003a) \\
\hline Other carnivores & Low densities & Close association between species & Pilot et al. (2018) \\
\hline \multirow[t]{3}{*}{ Wild ungulates } & Low density & Large home ranges, migratory behavior & $\begin{array}{l}\text { Haider et al. (2018); Joly } \\
\text { et al. (2019) }\end{array}$ \\
\hline & & Hunting and consumption & Zahler et al. (2004) \\
\hline & & Taxonomically similar to livestock & Walker et al. (2017) \\
\hline \multirow[t]{2}{*}{ Birds } & & Large congregations of migrating birds & Prins and Namgail (2017) \\
\hline & & High proportion of migratory species & Marchenko et al. (2012) \\
\hline \multirow[t]{2}{*}{ Rodents } & $\begin{array}{l}\text { Relatively low } \\
\text { abundance }\end{array}$ & Consumption of marmots for meat and medicine & Sariyeva et al. (2019) \\
\hline & & Relatively high densities of rodents in houses & Esson et al. (2019) \\
\hline \multicolumn{4}{|c|}{ Socio-ecological factors } \\
\hline Dogs & & Increasing abundance of feral dogs in the landscape & Young et al. (2011) \\
\hline Wildlife trade & & $\begin{array}{l}\text { Significant use of wild species in traditional medicinal } \\
\text { systems }\end{array}$ & (Byard 2016) \\
\hline \multirow[t]{2}{*}{ Land use } & $\begin{array}{l}\text { Low intensity of land } \\
\text { use }\end{array}$ & $\begin{array}{l}\text { High abundance of livestock and close association with } \\
\text { humans }\end{array}$ & $\begin{array}{l}\text { Mijiddorj et al. (2018), } \\
\text { Mishra et al. (2003b) }\end{array}$ \\
\hline & & High overlap in habitat use by livestock and wildlife & Mishra et al. (2004) \\
\hline \multicolumn{4}{|l|}{ Socio-economic factors } \\
\hline Human population & & Increasing human density and urbanization & $\begin{array}{l}\text { Mijiddorj et al. (2019), } \\
\text { Murali et al. (2019) }\end{array}$ \\
\hline $\begin{array}{l}\text { Infrastructure and } \\
\text { resource extraction }\end{array}$ & & $\begin{array}{l}\text { Increasing infrastructure development, mining, use of } \\
\text { pesticides, and integration with lowlands }\end{array}$ & $\begin{array}{l}\text { Snow Leopard Network } \\
\text { (2014) }\end{array}$ \\
\hline Wildlife trade & & Demand for pelt, bones, and other tissues & Nowell et al. (2016) \\
\hline
\end{tabular}

significant threat (Table 1). This has implications for EIDs through both the increased direct contact of humans and wildlife and the wider ecosystem impacts associated with species-poor communities. In parts of the world, it is likely that hunting, handling, and consumption of wildlife have led to some of the most serious zoonotic outbreaks in recent times (e.g., HIV/AIDS, SARS, COVID-19). Disease outbreaks are also linked to the wider ecosystem effects that result from severely reduced wildlife populations, e.g., African trypanosomiasis is thought to have resulted from tsetse flies (Glossina spp.) switching from depleted wildebeest (Connochaetes spp.) populations to feed on humans (Karesh et al. 2012; WHO 2020). Similarly, the
West Nile virus shows increased prevalence in speciespoor bird communities, and the transmission risk of hantavirus to humans is related to a lower diversity of small mammals in the local environment (Keesing et al. 2010). Thus, state-supported eradication programs for rodents, lagomorphs, and even large carnivores such as wolves (Canis lupus) in High Asia (Kaczensky et al. 2008; Wilson and Smith 2015; Wu and Wang 2017) that might be expected to reduce the risk of EIDs by reducing the number of potential reservoirs, vectors, and encounter rate, in some cases may intensify the risk of disease outbreaks through a disruption of natural ecosystem interactions that increases the movement and turnover of animals in the system: 
factors known to increase disease spread (Epstein et al. 2006).

Agricultural practices in High Asia are currently changing through intensification and homogenization that intensify the likelihood of disease amplification and transmission (Epstein et al. 2006): new areas are being brought under cropland (Namgail et al. 2007), there is reduction of crop and livestock diversity (Mishra et al. 2003b) and an increase in livestock densities (Berger et al. 2013). Modern livestock management and its interface with wildlife can result in increased cycling of bacterial strains that carry antibiotic resistance (Vittecoq et al. 2016), which can then be acquired and transported by wildlife, with omnivorous, anthropophilic, and carnivorous species being at higher risk because of their close interactions with livestock in this region (Arnold et al. 2016).

\section{Local socio-economic factors}

Rapid urbanization and population growth are currently occurring in High Asia (Tiwari et al. 2018; Murali et al. 2019). The 12 countries that form the global range of the snow leopard account for $42.6 \%$ of the world's human population (World Bank 2020). Many of these countries also encompass temperate and tropical zones that represent the geographical origins of several major known EIDs (e.g., bubonic plague, COVID-19, SARS, and Kyasanur Forest Disease (Bordier and Roger 2013)) and are currently considered as high risk areas. The local economies and production systems in High Asia are increasingly integrated with national economies, resulting in a high movement of goods and people between the mountains and lowlying areas (Mishra 2000; Berger et al. 2013; Snow Leopard Working Secretariat 2013). This includes a rapidly expanding tourism industry (Mavroidi 2008; Alexander et al. 2019; Mijiddorj et al. 2019). Large parts of High Asia are remote which results in law enforcement being difficult, increasing the possibility of illegal hunting of wildlife for consumption and trade (Mishra and Fitzherbert 2004; Zahler et al. 2004).

The number of feral dogs (Canis familiaris) in many areas of High Asia is increasing as a consequence of urbanization in countries such as Bhutan, China, India, Nepal, Pakistan, and Uzbekistan (Snow Leopard Network 2014). Feral and herding dogs also increase the links between remote habitats and urban centers, and facilitate pathogen transmission between wild species, livestock, and humans (Gascoyne et al. 1993; Randall et al. 2004; Budke et al. 2005).

Finally, High Asian landscapes form smaller, fringe parts of most of the constituent countries and are often considered remote and atypical. Hence, their national public services_-including public and animal health-are not specifically adapted to the local conditions. In addition, inadequate investments in health care services and disease surveillance in High Asia limit the ability to predict or prepare for possible outbreaks on both national and regional scales.

\section{Global factors}

High Asia is currently experiencing rapid transitions linked to globalization and climate change (Table 1). These changes have strong implications for increasing the risk of EIDs and zoonoses through introduction of new pathogens and vectors, habitat fragmentation, pollution, and human migration (Lerer and Scudder 1999; Patz et al. 2004).

The mountains and plateaus of High Asia are among the world's most vulnerable areas from a climate change perspective, warming at more than twice the average rate of the northern hemisphere (Li et al. 2016). Climate change will affect parasite-host assemblages, and likely result in increased frequency and intensification of disease outbreaks (Harvell et al. 2002; Brooks and Hoberg 2007; Fig. 3). In 2015, there was a mass mortality event of around 200000 saiga (Saiga tatarica) (65\% of the global population) due to hemorrhagic septicemia caused by the bacterium (Pasteurella multocida), which although outside the region we are describing, exemplifies the reality of changing climate influencing parasite-host interactions in ways which may lead to serious disease outbreaks and higher rates of mortality (Rohr et al. 2013; Kock et al. 2018).

The once remote landscapes of High Asia are now under considerable pressures of economic and infrastructure development, resulting in the opening up of remote habitats and increasing integration with lowlands and mainstream economies (Snow Leopard Working Secretariat 2013; Snow Leopard Network 2014;). These infrastructure developments include mining, gas and oil pipelines, new roads and railways, and large dams (Grumbine and Pandit 2013; Snow Leopard Network 2014; Ascensão et al. 2018). Such large development projects are associated with pollution and immigration of workers from outside areas, opening up new markets for livestock and wildlife trade, and introducing foreign pathogens and vectors (Kilpatrick and Randolph 2012; Hassell et al. 2017). There are also unprecedented levels of long-distance movement of people and goods between High Asia and the rest of the world, creating strong pathways for the spread of disease both into and out of the region (Berger et al. 2013).

\section{PATHOGEN PREVALENCE IN HIGH ASIA}

Knowledge of pathogen prevalence and disease transmission within and between wildlife and domestic animal 
populations of High Asia is limited and scattered. Nevertheless, it is evident from the available information that many virulent pathogens with the potential to cause widespread mortality and morbidity, in both animals and people, already exist in the animal populations in High Asia (Table 2). These pathogens and potential disease outbreaks have serious implications for both the health of people and their livelihoods and the conservation of wildlife not just in High Asia, but they also pose a global challenge (Daszak et al. 2000).

\section{Snow leopards}

Research on disease in wild snow leopards has been very limited and most information to date comes from captive animals. Our work in Tost Mountains of Mongolia discovered antibodies to several zoonotic pathogens in wild

Table 2 Main zoonoses in High Asia sorted by type of disease (viral, bacterial, and parasitic) and main hosts involved

\begin{tabular}{|c|c|c|c|c|}
\hline Disease & Pathogen & Main hosts & Mode of transmission & References \\
\hline \multicolumn{5}{|l|}{ Viruses } \\
\hline Rabies & Rabies virus & Carnivores and bats & Bites and saliva & Ebright et al. (2003) \\
\hline SARS & SARS-coronavirus & $\begin{array}{l}\text { Bats and possibly small } \\
\text { carnivores }\end{array}$ & Airborne droplets & $\begin{array}{l}\text { Bell et al. (2004); Li et al. (2005); Ye } \\
\text { et al. (2020) }\end{array}$ \\
\hline MERS & MERS-coronavirus & Bats and possibly camels & Airborne droplets & $\begin{array}{l}\text { Ramadan and Shaib (2019); Ye et al. } \\
\text { (2020) }\end{array}$ \\
\hline COVID-19 & SARS-coronavirus 2 & Likely bats & Airborne droplets & Malik et al. (2020); Ye et al. 2020) \\
\hline Avian influenza & $\begin{array}{l}\text { Influenza A virus subtype } \\
\text { H5N1 }\end{array}$ & Birds & & Marchenko et al. (2012) \\
\hline Swine influenza & $\begin{array}{l}\text { Influenza A virus subtype } \\
\text { H1N1 }\end{array}$ & Pigs & Airborne droplets & Kothalawala et al. (2006) \\
\hline Hantavirus & Hantavirus & Rodents & Airborne transmission & Bi et al. (2008) \\
\hline $\begin{array}{l}\text { Japanese } \\
\text { encephalitis }\end{array}$ & $\begin{array}{l}\text { Japanese encephalitis } \\
\text { virus }\end{array}$ & Birds and possibly pigs & Vectors & Ladreyt et al. (2019) \\
\hline Influenza & Influenza A virus & Birds & Airborne droplets & Webby et al. (2007) \\
\hline \multicolumn{5}{|l|}{ Bacteria } \\
\hline Anthrax & Bacillus anthracis & Ungulates & Inhalation and ingestion & Ebright et al. (2003) \\
\hline Plague & Yersinia pestis & Rodents & Arthropod vectors & $\begin{array}{l}\text { Alfani and Murphy (2017); Ebright et al. } \\
\text { (2003) }\end{array}$ \\
\hline Tuberculosis & Mycobacterium spp. & $\begin{array}{l}\text { Birds, mammals, and } \\
\text { reptiles }\end{array}$ & $\begin{array}{l}\text { Airborne droplets and } \\
\text { aerosols }\end{array}$ & De Lisle et al. (2002) \\
\hline Brucellosis & Brucella spp. & Ungulates & Ingestion & Ebright et al. (2003) \\
\hline Leptospirosis & Leptospira spp. & $\begin{array}{l}\text { Rodents and other } \\
\text { mammals }\end{array}$ & Ingestion, broken skin & Victoriano et al. (2009) \\
\hline Tularemia & Francisella tularensis & Mammals and birds & $\begin{array}{l}\text { Vectors, ingestion, and } \\
\text { air }\end{array}$ & Keim et al. (2007) \\
\hline $\begin{array}{l}\text { Cat-scratch } \\
\text { disease }\end{array}$ & Bartonella spp. & Rodents and felids & Vectors & Chomel and Kasten (2010) \\
\hline Q fever & Coxiella burnetii & $\begin{array}{l}\text { Ungulates and other } \\
\text { mammals }\end{array}$ & Airborne aerosols & Gonzalez-Barrio and Ruiz-Fons (2019) \\
\hline Lyme disease & Borrelia burgdorferi & Rodents and ungulates & Arthropod vectors & Anderson (1988); Levi et al. (2012) \\
\hline \multicolumn{5}{|l|}{ Parasites } \\
\hline Echinococcosis & Echinococcus spp. & $\begin{array}{l}\text { Canids, rodents, and } \\
\text { ungulates }\end{array}$ & Ingestion & Otero-Abad and Torgerson (2013) \\
\hline Trichinosis & Trichinella spp. & Pigs and carnivores & Ingestion & Kagan (1960) \\
\hline Giardiasis & Giardia duodenalis & Mammals and birds & Ingestion & Appelbee et al. (2005) \\
\hline Toxoplasmosis & Toxoplasma gondii & Mammals and birds & Ingestion & Dubey (2010) \\
\hline Cryptosporidiosis & Cryptosporidium spp. & Mammals and birds & Ingestion & Appelbee et al. (2005) \\
\hline
\end{tabular}

Included in the table is also the main mode of transmission 
snow leopards (Esson et al. 2019). Other pathogens from the study in Mongolia included Coxiella burnetii, the sublethal but highly virulent bacterium often found in livestock that causes $\mathrm{Q}$ fever in humans; the protozoan parasite Toxoplasma gondii that causes Toxoplasmosis; and bacteria belonging to the genus Leptospira that cause potentially life-threatening Leptospirosis in humans (Esson et al. 2019). In the same study, we recorded several zoonotic bacteria from ectoparasitic ticks collected from snow leopards belonging to the genera Bacillus, Bacteroides, Campylobacter, Coxiella, Rickettsia, Staphylococcus, and Streptococcus. Bacteria within these genera are responsible for severe illnesses in humans including anaplasmosis, Q fever, ehrlichiosis, and anthrax. Among other common bacterial zoonosis, tuberculosis has been reported in captive snow leopards but there are no reports of plague or anthrax in either wild or captive snow leopards (Helman et al. 1998). However, confirmed existence of plague and related zoonosis from marmots, anthrax in wild ungulate prey of snow leopards, and the fact that felids like mountain lions Puma concolor act as vectors for plague and anthrax, render them a potentially serious concern for snow leopards (Hugh-Jones and de Vos 2002). There are several viral diseases reported in captive snow leopards that are typically specific to felines such as feline coronavirus, feline parvovirus, calicivirus, feline immunodeficiency virus, feline panleukopenia, feline papillomavirus, canine distemper virus, and papillomavirus (Kennedy et al. 2002; Mitsouras et al. 2011; Ostrowski and Gilbert 2016). COVID-19 was also reported in three captive snow leopards in USA (Andrew 2020). The only study on viral diseases in free-ranging snow leopards to date found that four of six sampled snow leopards had been infected by rotavirus. The study also reported infections of felid herpesvirus 1 and feline papillomavirus 2 (Johansson et al. 2020b). Snow leopards from the same study area also carried antibodies against feline corona virus (Snow Leopard Trust, unpublished data). While there are no reports of snow leopards dying from any of these diseases, felids in other parts of the world are known to die from diseases such as canine distemper virus, rendering diseases a potentially serious concern in snow leopard landscapes (Roelke-Parker et al. 1997).

\section{Canids}

Both wild and domestic canids in High Asia carry important zoonotic diseases, and since herding and feral dogs interact with people, livestock, and wildlife, they are an important potential route for disease transmission as occurred with rabies outbreaks in African wild dogs ( $L y$ caon pictus) and Ethiopian wolves (Canis simensis)
(Gascoyne et al. 1993; Randall et al. 2004). Rabies has been reported in foxes, $\operatorname{dogs}$, and wolves in High Asia (Boldbaatar et al. 2010), but its current impacts and future emergence potential are uncertain. Echinococcosis, a zoonotic infection caused by tapeworms from the genus Echinococcus has seen a recent re-emergence in Central Asia (Torgerson et al. 2006; Ziadinov et al. 2008), with the parasite largely prevalent in feral and herding dogs, and red foxes (Vulpes Vulpes) acting as reservoirs (Kruse et al. 2004).

\section{Ungulates}

Potentially zoonotic diseases such as sarcoptic mange and mycoplasmosis have caused mortalities of ungulates including blue sheep (Pseudois nayaur) and markhor (Capra falconeri) in the mountains of Pakistan and Tajikistan, respectively. These outbreaks are linked to transfer from sympatric livestock (Dagleish et al. 2007; Ostrowski et al. 2011). Bubonic plague (Yersinia pestis) and anthrax (Bacillus anthracis) are also carried by wild ungulates and smaller prey taken by snow leopards, such as marmots (Marmota baibacina) (Sariyeva et al. 2019). Marmots are hunted by people for their meat in large parts of the snow leopard range, and associated human deaths from plague transmission have been reported recently (Grewal 2020).

\section{Bats}

Research on bat distribution and related zoonotic diseases has been limited across High Asia (Mackenzie and Williams 2009; Gay et al. 2014), despite them being common and known to carry some of the most serious zoonotic diseases in the world (Kuzmin et al. 2006; Luis et al. 2013). Kuzmin et al. (2006) isolated rabies virus from two different bat species from parts of High Asia, and species of horseshoe bats (e.g., Rhinolophus ferrumequinum, $R$. hipposideros, and $R$. sinicus), known to host various types of coronaviruses (including SARS and COVID-19) are also present (Hu et al. 2017; Zhou et al. 2020); albeit with lower abundance than most low-lying areas. The presence of Anaplasma bacterial infection in ticks from the QinghaiTibetan plateau has been confirmed with bats being suggested as potential hosts (Han et al. 2019). In the relative cold and harsh environment of High Asia, many bat species hibernate in large groups through the winter (Geiser and Turbill 2009), increasing the risk of disease transmission. Similarly, current anthropogenic habitat modifications are likely to increase exposure to, and drive behavior-related changes in bats that increase the risk of disease transmission to humans, livestock, and other wildlife (Hayman et al. 2013). 


\section{Birds}

Avian influenza is a zoonotic EID that can cause disease symptoms in birds and people that range from mild respiratory symptoms to acute respiratory distress and death $(\mathrm{Hu}$ et al. 2011; Marchenko et al. 2012). A large outbreak of H5N1 influenza virus occurred in Qinghai lake, China in 2005 and viruses from the same clade were discovered in Mongolia, Russia, Europe, and Africa along the birds' migratory flyways. Since then, several outbreaks of avian influenza have occurred in the snow leopard distribution area (Hu et al. 2011). Marchenko et al. (2012) sampled birds belonging to six orders across Kazakhstan, Mongolia, and Russia and found six isolates of the avian influenza virus in Mongolia and Russia. The risk of zoonoses and EIDs from migratory bird populations in High Asia remains significant and is likely increasing.

\section{CONCLUSIONS AND THE WAY AHEAD}

The cold and arid mountains and plateaus of High Asia have so far been considered at low risk of disease emergence, and thus, relatively neglected from the perspective of disease research, and their potential implications for human health and biodiversity conservation (Jones et al. 2008; Allen et al. 2017). However, a closer examination of the region shows that with ongoing changes in ecological, socio-ecological, and socio-economic factors, there is an increased potential for EID outbreaks that could have large impact on local communities and biodiversity conservation (Fig. 3). Increased movement of people and livestock along the regional 'Belt and Road Initiative' is projected to increase the risk of diseases through several countries within High Asia (Hughes et al. 2020). Global factors including climate change and globalization further intensify this risk (Lerer and Scudder 1999; Patz et al. 2004) and as has been demonstrated well by recent pandemics, local disease outbreaks now have the potential to threaten humans and animals around the world due to globalization (Daszak et al. 2000).

Thus, there is an urgent need for inter-sectoral (human and animal health, agriculture, and conservation) and multi-disciplinary engagement in setting up long-term disease surveillance programs across High Asia. These programs need to not only focus on EIDs and zoonoses of current concern, but also engage in long-term strategic monitoring of endemic diseases within wildlife and domestic livestock to help understand how interactions among these pools may affect each other, and to help understand where new EIDs may arise. This needs to be accompanied by a systematic strengthening of health systems in these remote areas to ensure appropriate health care and well-being of local communities, which in turn, will indirectly provide wider benefits at the national and global levels by earlier detection and preparedness for EIDs and zoonoses (Daszak et al. 2000; Al-Kindi 2020). Currently, most surveillance in many low- and middle-income countries occurs is in isolation, with limited data-sharing and lack of integrated responses during outbreaks (Chatterjee et al. 2016). Thus, wide-scale changes in this area are urgently needed, for example, recent policy recommendations in India (National Mission on Biodiversity and Human Well-being), which aim to work towards a healthier and more sustainable way of life, for people and nature (Bawa et al. 2020).

We suggest that research and management of potential EIDs and zoonoses must become a priority for human welfare and biodiversity conservation in High Asia. Spatially explicit monitoring of factors that increase the risk of disease outbreaks is necessary (Daszak et al. 2000). This is especially important today when climate change and increasing globalization are favoring EIDs and zoonoses (Harvell et al. 2002; Jones et al. 2008). Moreover, the growing rate of poaching and illegal wildlife trade needs to be disrupted through stronger law enforcement, and better cooperation among governments, conservationists, and local communities (Cooney et al. 2017). We also call for raising awareness among local and global communities about the threat of EIDs and zoonotic diseases and discourage the use of wild animal products (Daszak et al. 2000). Better veterinary care of livestock and stronger training of vets in wildlife diseases is also needed. Controlling feral dog populations where they have become a conservation management problem as well as human health hazard is important as well (Young et al. 2011).

There is great need and opportunity to enable sustainable economies that maintain the integrity and resilience of natural ecosystems of High Asia, which, in addition to improving human well-being, can help maintain systemic resilience against disease emergence. Promoting green infrastructure, organic farming, and green economies that minimize ecosystem damage, while supporting enterprises that are dependent on ecosystem services can help ensure a healthy and sustainable future for humans and biodiversity in High Asia, with positive global consequences.

As we have suggested in this review, and as the world has witnessed in the outbreaks of zoonoses such as SARS and COVID-19, concerns of human and environmental health and the well-being of people and ecosystems are intricately linked and global in nature (the 'One Health' concept; Harvell et al. 2002; Jones et al. 2008). Human health and well-being and the well-being of ecosystems should not be treated as separate policy realms, or viewed as local health or conservation problems, but instead be viewed and managed as integrated entities (Daszak et al. 
2000). We therefore reiterate that there is need for holistic development of sustainable health, economic, and biodiversity conservation systems, particularly, in High Asia and other regions with similar settings and changes. With its significant geographical extent, often healthy ecosystems, clean water resources, and other ecosystem services, High Asia offers great opportunities to contribute sustainably towards better planetary health (Whitmee et al. 2015). The high-level inter-governmental alliance of 12 countries focused on snow leopard conservation in High Asia, called the Global Snow Leopard and Ecosystem Protection Program (Snow Leopard Working Secretariat 2013), can play a pivotal role in prioritizing human and wildlife health issues and addressing these various needs.

Acknowledgements We are thankful to the Whitley Fund for Nature for supporting our conservation efforts, and enabling this review. PNS time contributions were supported by the DBT/Wellcome Trust India Alliance Fellowship to him [IA/CPHI/16/1/502648].

Author contributions CM, GS and ÖJ conceived the ideas. All authors contributed critically to the drafts and gave approval for publication.

Funding Open access funding provided by Swedish University of Agricultural Sciences.

Open Access This article is licensed under a Creative Commons Attribution 4.0 International License, which permits use, sharing, adaptation, distribution and reproduction in any medium or format, as long as you give appropriate credit to the original author(s) and the source, provide a link to the Creative Commons licence, and indicate if changes were made. The images or other third party material in this article are included in the article's Creative Commons licence, unless indicated otherwise in a credit line to the material. If material is not included in the article's Creative Commons licence and your intended use is not permitted by statutory regulation or exceeds the permitted use, you will need to obtain permission directly from the copyright holder. To view a copy of this licence, visit http://creativecommons. org/licenses/by/4.0/.

\section{REFERENCES}

Al-Kindi, K.M., A. Alkharusi, D. Alshukaili, N. Al Nasiri, T. AlAwadhi, Y. Charabi, and A.M. El Kenawy. 2020. Spatiotemporal assessment of COVID-19 spread over Oman using GIS techniques. Earth Systems and Environment 4: 797-811. https://doi. org/10.1007/s41748-020-00194-2.

Alexander, J.S., R. Murali, A. Bijoor, L. Yuhan, and C. Mishra. 2019. Principles and recommendations for tourism with snow leopard habitats. Bishkek: Global snow leopard ecosystem protection plan.

Alfani, G., and T.E. Murphy. 2017. Plague and lethal epidemics in the pre-industrial world. The Journal of Economic History 77: 314-343. https://doi.org/10.1017/s0022050717000092.

Allen, T., K.A. Murray, C. Zambrana-Torrelio, S.S. Morse, C. Rondini, M. Di Marco, N. Breit, K.J. Olival, et al. 2017. Global hotspots and correlates of emerging zoonotic diseases. Nature
Communications 8: 1124. https://doi.org/10.1038/s41467-01700923-8.

Altizer, S., R. Bartel, and B.A. Han. 2011. Animal migration and infectious disease risk. Science 331: 296-302. https://doi.org/10. 1126/science. 1194694.

Anderson, J.F. 1988. Mammalian and avian reservoirs for BorreliaBurgdorferi. Annals of the New York Academy of Sciences 539: 180-191. https://doi.org/10.1111/j.1749-6632.1988.tb31852.x.

Andrew S. 2020. Three snow leopards test positive for coronavirus, making it the sixth confirmed animal species. https://edition.cnn. com/2020/12/11/us/snow-leopard-positive-coronaviruskentucky-zoo-trnd/index.html. Accessed 13 December 2020

Appelbee, A.J., R.C. Thompson, and M.E. Olson. 2005. Giardia and Cryptosporidium in mammalian wildlife-current status and future needs. Trends in Parasitology 21: 370-376. https://doi. org/10.1016/j.pt.2005.06.004.

Arnold, K.E., N.J. Williams, and M. Bennett. 2016. "Disperse abroad in the land": The role of wildlife in the dissemination of antimicrobial resistance. Biology Letters. https://doi.org/10. 1098/rsbl.2016.0137.

Ascensão, F., L. Fahrig, A.P. Clevenger, R.T. Corlett, J.A.G. Jaeger, W.F. Laurance, and H.M. Pereira. 2018. Environmental challenges for the belt and road initiative. Nature Sustainability 1: 206-209. https://doi.org/10.1038/s41893-018-0059-3.

Bawa, K.S., N. Nawn, R. Chellam, J. Krishnaswamy, V. Mathur, S.B. Olsson, N. Pandit, P. Rajagopal, et al. 2020. Opinion: Envisioning a biodiversity science for sustaining human well-being. Proceedings of the National Academy of Science U S A 117: 25951-25955. https://doi.org/10.1073/pnas.2018436117.

Bell, D., S. Roberton, and P.R. Hunter. 2004. Animal origins of SARS coronavirus: Possible links with the international trade in small carnivores. Philosophical Transactions of the Royal Society of London B 359: 1107-1114. https://doi.org/10.1098/rstb.2004. 1492.

Berger, J., B. Buuveibaatar, and C. Mishra. 2013. Globalization of the cashmere market and the decline of large mammals in central Asia. Conservation Biology 27: 679-689. https://doi.org/10. 1111/cobi.12100.

Bi, Z., P.B.H. Formenty, and C.E. Roth. 2008. Hantavirus infection: A review and global update. Journal of Infection in Developing Countries 2: 3-23.

Boldbaatar, B., S. Inoue, N. Tuya, P. Dulam, D. Batchuluun, N. Sugiura, A. Okutani, Y. Kaku, et al. 2010. Molecular epidemiology of rabies virus in Mongolia, 2005-2008. Japanese Journal of Infectious Disease 63: 358-363.

Bordier, M., and F. Roger. 2013. Zoonoses in South-East Asia: A regional burden, a global threat. Animal Health Research Reviews 14: 40-67. https://doi.org/10.1017/ S1466252313000017.

Brooks, D.R., and E.P. Hoberg. 2007. How will global climate change affect parasite-host assemblages? Trends in Parasitology 23: 571-574. https://doi.org/10.1016/j.pt.2007.08.016.

Budke, C.M., Q. Jiamin, P.S. Craig, and P.R. Torgerson. 2005. Modeling the transmission of Echinococcus granulosus and Echinococcus multilocularis in dogs for a high endemic region of the Tibetan plateau. International Journal of Parasitology 35: 163-170. https://doi.org/10.1016/j.ijpara.2004.10.026.

Byard, R.W. 2016. Traditional medicines and species extinction: Another side to forensic wildlife investigation Forensic Science. Medicine, and Pathology 12: 125-127. https://doi.org/10.1007/ s12024-016-9742-8.

Chatterjee, P., M. Kakkar, and S. Chaturvedi. 2016. Integrating one health in national health policies of developing countries: India's lost opportunities. Infectious Diseases of Poverty 5: 87. https:// doi.org/10.1186/s40249-016-0181-2. 
Chomel, B.B., and R.W. Kasten. 2010. Bartonellosis, an increasingly recognized zoonosis. Journal of Applied Microbiology 109: 743-750. https://doi.org/10.1111/j.1365-2672.2010.04679.x.

Cooney, R., D. Roe, H. Dublin, J. Phelps, D. Wilkie, A. Keane, H. Travers, D. Skinner, et al. 2017. From poachers to protectors: Engaging local communities in solutions to illegal wildlife trade. Conservation Letters 10: 367-374. https://doi.org/10.1111/conl. 12294.

Dagleish, M.P., Q. Ali, R.K. Powell, D. Butz, and M.H. Woodford. 2007. Fatal Sarcoptes scabiei Infection of Blue Sheep (Pseudois nayaur) in Pakistan. Journal of Wildlife Diseases 43: 512-517.

Daszak, P., A.A. Cunningham, and A.D. Hyatt. 2000. Wildlife ecology-Emerging infectious diseases of wildlife-Threats to biodiversity and human health. Science 287: 443-449. https:// doi.org/10.1126/science.287.5452.443.

De Lisle, G.W., R.G. Bengis, S.M. Schmitt, and D.J. O’Brien. 2002. Tuberculosis in free ranging wildlife: Detection, diagnosis and management. Revue Scientifique Et Technique (international Office of Epizootics) 21: 317-334.

Dubey, J. 2010. Toxoplasmosis of animals and humans, 2nd ed. Boca Raton: Taylor \& Francis Group.

Ebright, J.R., T. Altantsetseg, and R. Oyungerel. 2003. Emerging infectious diseases in Mongolia. Emerging Infectious Diseases 9: 1509-1515. https://doi.org/10.3201/eid0912.020520.

Epstein, J., H. Field, S. Luby, J.R. Pulliam, and P. Daszak. 2006. Nipah virus: Impact, origins and causes of emergence. Current Infectious Disease Reports 8: 59-65.

Esson, C., L.F. Skerratt, L. Berger, J. Malmsten, T. Strand, A. Lundkvist, J.D. Jarhult, J. Michaux, et al. 2019. Health and zoonotic Infections of snow leopards Panthera unica in the South Gobi desert of Mongolia. Infection Ecology and Epidemiology 9: 1604063. https://doi.org/10.1080/20008686.2019. 1604063.

Fox, J.L., and R.S. Chundawat. 2016. What is a snow leopard? Behavior and ecology. In Snow Leopards. Biodiversity of the World, ed. D.P. Mallon. London: Elsevier.

Gascoyne, S.C., M.K. Laurenson, S. Lelo, and M. Borner. 1993. Rabies in African wild dogs (Lycaon-Pictus) in the Serengeti Region, Tanzania. Journal of Wildlife Diseases 29: 396-402. https://doi.org/10.7589/0090-3558-29.3.396.

Gay, N., K.J. Olival, S. Bumrungsri, B. Siriaroonrat, M. Bourgarel, and S. Morand. 2014. Parasite and viral species richness of Southeast Asian bats: Fragmentation of area distribution matters. International Journal of Parasitology, Parasites and Wildlife 3: 161-170. https://doi.org/10.1016/j.ijppaw.2014.06. 003.

Geiser, F., and C. Turbill. 2009. Hibernation and daily torpor minimize mammalian extinctions. Naturwissenschaften 96: 1235-1240. https://doi.org/10.1007/s00114-009-0583-0.

Gonzalez-Barrio, D., and F. Ruiz-Fons. 2019. Coxiella burnetii in wild mammals: A systematic review. Transboundary and Emerging Diseases 66: 662-671. https://doi.org/10.1111/tbed. 13085 .

Graham-Rowe, D. 2011. Biodiversity: Endangered and in demand. Nature 480: S101-S103. https://doi.org/10.1038/480S101a.

Grewal K. 2020. All about the "Black Death" Bubonic plague that has China on high alert.The Print. https://theprint.in/theprintessential/all-about-the-black-death-bubonic-plague-that-haschina-on-high-alert/455546/. Accessed 7 July 2020

Grumbine, R.E., and M.K. Pandit. 2013. Threats from India's Himalaya Dams. Science 339: 36-37. https://doi.org/10.1126/ science. 1227211.

Haider, J., M.Z. Khan, M. Anwer, S. Ali, and H. Ali. 2018. Population status and migration trends of Marco Polo argali (Ovis ammon polii) in Pakistan. Mammalia 82: 481-485. https://doi.org/10. 1515/mammalia-2017-0121.
Han, R., J.F. Yang, M.U. Mukhtar, Z. Chen, Q.L. Niu, Y.Q. Lin, G.Y. Liu, J.X. Luo, et al. 2019. Molecular detection of Anaplasma infections in ixodid ticks from the Qinghai-Tibet Plateau. Infectious Diseases of Poverty 8: 12. https://doi.org/10.1186/ s40249-019-0522-z.

Harvell, C.D., C.E. Mitchell, J.R. Ward, S. Altizer, A.P. Dobson, R.S. Ostfeld, and M.D. Samuel. 2002. Ecology - Climate warming and disease risks for terrestrial and marine biota. Science 296: 2158-2162. https://doi.org/10.1126/science.1063699.

Hassell, J.M., M. Begon, M.J. Ward, and E.M. Fevre. 2017. Urbanization and disease emergence: dynamics at the wildlifelivestock-human interface. Trends in Ecology and Evolution 32: 55-67. https://doi.org/10.1016/j.tree.2016.09.012.

Hayman, D.T., R.A. Bowen, P.M. Cryan, G.F. McCracken, T.J. O'Shea, A.J. Peel, A. Gilbert, C.T. Webb, et al. 2013. Ecology of zoonotic infectious diseases in bats: Current knowledge and future directions. Zoonoses and Public Health 60: 2-21. https:// doi.org/10.1111/zph.12000.

Helman, R.G., W.C. Russell, A. Jenny, J. Miller, and J. Payeur. 1998. Diagnosis of tuberculosis in two snow leopards using polymerase chain reaction. Journal of Veterinary Diagnostic Investigation 10: 89-92.

Hu, X., D. Liu, M. Wang, L. Yang, M. Wang, Q. Zhu, X. Li, G.F. Gao. 2011. Clade 2.3.2 Avian Influenza Virus (H5N1), Qinghai Lake Region, China, 2009-2010. Emerging Infectious Diseases 17: 560-562.

Hu, B., L.P. Zeng, X.L. Yang, X.Y. Ge, W. Zhang, B. Li, J.Z. Xie, X.R. Shen, et al. 2017. Discovery of a rich gene pool of bat SARS-related coronaviruses provides new insights into the origin of SARS coronavirus. PLoS Pathogens 13: e1006698. https://doi.org/10.1371/journal.ppat.1006698.

Hugh-Jones, M.E., and V. de Vos. 2002. Anthrax and wildlife. Scientific and Technical Review of the Office International Des Epizooties (paris) 21: 359-383.

Hughes, A.C., A.M. Lechner, A. Chitov, A. Horstmann, A. Hinsley, A. Tritto, A. Chariton, B.V. Li, et al. 2020. Horizon scan of the belt and road initiative. Trends in Ecology \& Evolution 35: 583-593. https://doi.org/10.1016/j.tree.2020.02.005.

Johansson, Ö., T. McCarthy, G. Samelius, H. Andrén, L. Tumursukh, and C. Mishra. 2015. Snow leopard predation in a livestock dominated landscape in Mongolia. Biological Conservation 184: 251-258. https://doi.org/10.1016/j.biocon.2015.02.003.

Johansson, Ö., G.R. Rauset, G. Samelius, T. McCarthy, H. Andrén, L. Tumursukh, and C. Mishra. 2016. Land sharing is essential for snow leopard conservation. Biological Conservation 203: 1-7.

Johansson, Ö., G. Ausilio, M. Low, P. Lkhagvajav, B. Weckworth, and K. Sharma. 2020a. The timing of breeding and independence for snow leopard females and their cubs. Mammalian Biology. https://doi.org/10.1007/s42991-020-00073-3.

Johansson, Ö., K. Ullman, P. Lkhagvajav, M. Wiseman, J. Malmsten, and M. Leijon. 2020b. Detection and genetic characterization of viruses present in free-ranging snow leopards using nextgeneration sequencing. Frontiers in Veterinary Science 7: 645. https://doi.org/10.3389/fvets.2020.00645.

Joly, K., E. Gurarie, M.S. Sorum, P. Kaczensky, M.D. Cameron, A.F. Jakes, B.L. Borg, D. Nandintsetseg, et al. 2019. Longest terrestrial migrations and movements around the world. Scientific Reports 9: 15333. https://doi.org/10.1038/s41598-01951884-5.

Jones, K.E., N.G. Patel, M.A. Levy, A. Storeygard, D. Balk, J.L. Gittleman, and P. Daszak. 2008. Global trends in emerging infectious diseases. Nature 451: 990-U994. https://doi.org/10. 1038/nature06536.

Jumabay-Uulu, K., P. Wegge, C. Mishra, and K. Sharma. 2013. Large carnivores and low diversity of optimal prey: A comparison of the diets of snow leopards Panthera uncia and wolves Canis 
lupus in Sarychat-Ertash Reserve in Kyrgyzstan. Oryx 48: 529-535. https://doi.org/10.1017/s0030605313000306.

Kaczensky, P., N. Enkhsaikhan, O. Ganbaatar, and C. Walzer. 2008. The Great Gobi B strictly protected area in Mongolia - refuge or sink for wolves Canis lupus in the Gobi. Wildlife Biology 14: 444-456. https://doi.org/10.2981/0909-6396-14.4.444.

Kagan, I.G. 1960. Trichinosis: A review of biologic, serologic and immunologic aspects. Journal of Infectious Diseases 107: 65-93.

Karanth, K.U., J.D. Nichols, N.S. Kumar, W.A. Link, and J.E. Hines. 2004. Tigers and their prey: Predicting carnivore densities from prey abundance. Proceedings of the National Academy of Sciences 101: 4854-4858. https://doi.org/10.1073/pnas. 0306210101.

Karesh, W.B., A. Dobson, J.O. Lloyd-Smith, J. Lubroth, M.A. Dixon, M. Bennett, S. Aldrich, T. Harrington, et al. 2012. Ecology of zoonoses: Natural and unnatural histories. The Lancet 380: 1936-1945. https://doi.org/10.1016/s0140-6736(12)61678-x.

Keesing, F., L.K. Belden, P. Daszak, A. Dobson, C.D. Harvell, R.D. Holt, P. Hudson, A. Jolles, et al. 2010. Impacts of biodiversity on the emergence and transmission of infectious diseases. Nature 468: 647-652. https://doi.org/10.1038/nature09575.

Keim, P., A. Johansson, and D.M. Wagner. 2007. Molecular epidemiology, evolution, and ecology of Francisella. Annals of the New York Academy of Sciences 1105: 30-66. https://doi.org/ 10.1196/annals.1409.011.

Kennedy, M., S. Citino, A.H. McNabb, A.S. Moffatt, K. Gertz, and S. Kania. 2002. Detection of feline coronavirus in captive Felidae in the USA. Journal of Veterinary Diagnostic Investigation 14: 520-522. https://doi.org/10.1177/104063870201400615.

Kilpatrick, A.M., and S.E. Randolph. 2012. Drivers, dynamics, and control of emerging vector-borne zoonotic diseases. The Lancet 380: 1946-1955. https://doi.org/10.1016/s0140-6736(12)611519.

Kock, R.A., M. Orynbayev, S. Robinson, S. Zuther, N.J. Singh, W. Beauvais, E.R. Morgan, A. Kerimbayev, et al. 2018. Saigas on the brink: Multidisciplinary analysis of the factors influencing mass mortality events. Science Advances. https://doi.org/10. 1126/sciadv.aao2314.

Kothalawala, H., M.J.M. Toussaint, and E. Gruys. 2006. An overview of swine influenza. Veterinary Quarterly 28: 45-53. https://doi. org/10.1080/01652176.2006.9695207.

Krauss, S., D.E. Stallknecht, N.J. Negovetich, L.J. Niles, R.J. Webby, and R.G. Webster. 2010. Coincident ruddy turnstone migration and horseshoe crab spawning creates an ecological "hot spot" for influenza viruses. Proceedings of the Royal Society B 277: 3373-3379. https://doi.org/10.1098/rspb.2010.1090.

Kruse, H., A.-M. Kirkemo, and K. Handeland. 2004. Wildlife as a source of zoonotic infections. Emerging Infectious Diseases 10: 2067-2072.

Kuzmin, I.V., A.D. Botvinkin, E.M. Poleschuk, L.A. Orciari, and C.E. Rupprecht. 2006. Bat rabies surveillance in the former Soviet Union. Developments in Biologicals 125: 273-282.

Ladreyt, H., B. Durand, P. Dussart, and V. Chevalier. 2019. How central is the domestic pig in the epidemiological cycle of Japanese Encephalitis virus? A Review of Scientific Evidence and Implications for Disease Control. Viruses. https://doi.org/10. 3390/v11100949.

Lerer, L.B., and T. Scudder. 1999. Health impact of large dams. Environmental Impact Assessment Review 19: 113-123.

Levi, T., A.M. Kilpatrick, M. Mangel, and C.C. Wilmers. 2012. Deer, predators, and the emergence of Lyme disease. Proceedings of the National Academy of Sciences 109: 10942-10947. https:// doi.org/10.1073/pnas.1204536109.

Li, J., and Z. Lu. 2014. Snow leopard poaching and trade in China 2000-2013. Biological Conservation 176: 207-211. https://doi. org/10.1016/j.biocon.2014.05.025.
Li, J., T. McCarthy, H. Wang, B. Weckworth, G.B. Schaller, C. Mishra, Z. Lu, and S.R. Beissinger. 2016. Climate refugia of snow leopards in High Asia. Biological Conservation 203: 188-196. https://doi.org/10.1016/j.biocon.2016.09.026.

Li, W., Z. Shi, M. Yu, W. Ren, C. Smith, J.H. Epstein, H. Wang, G. Crameri, et al. 2005. Bats are natural reservoirs of SARS-like coronaviruses. Science 310: 676-679. https://doi.org/10.1126/ science.1118391.

Lindahl, J.F., and D. Grace. 2015. The consequences of human actions on risks for infectious diseases: A review. Infection Ecology and Epidemiology 5: 30048. https://doi.org/10.3402/iee.v5.30048.

Luis, A.D., D.T. Hayman, T.J. O’Shea, P.M. Cryan, A.T. Gilbert, J.R. Pulliam, J.N. Millis, M.E. Timonin, et al. 2013. A comparison of bats and rodents as reservoirs of zoonotic viruses: Are bats special? Proceedings of the Royal Society B 280: 20122753. https://doi.org/10.1098/rspb.2012.2753.

Mackenzie, J.S., and D.T. Williams. 2009. The zoonotic flaviviruses of southern, south-eastern and eastern Asia, and Australasia: The potential for emergent viruses. Zoonoses and Public Health 56: 338-356. https://doi.org/10.1111/j.1863-2378.2008.01208.x.

Mainka, S.A., and J.A. Mills. 1995. Wildlife and traditional Chinese medicine: Supply and demand for wildlife species. Journal of Zoo and Wildlife Medicine 26: 193-200.

Malik, Y.S., S. Sircar, S. Bhat, K. Sharun, K. Dhama, M. Dadar, R. Tiwari, and W. Chaicumpa. 2020. Emerging novel coronavirus (2019-nCoV)-current scenario, evolutionary perspective based on genome analysis and recent developments. Veterinary Quarterly 40: 68-76. https://doi.org/10.1080/01652176.2020.1727993.

Marchenko, V.Y., A.Y. Alekseev, K.A. Sharshov, V.N. Petrov, N.Y. Silko, I.M. Susloparov, D. Tserennorov, D. Otgonbaatar, et al. 2012. Ecology of influenza virus in wild bird populations in Central Asia. Avian Diseases 56: 234-237. https://doi.org/10. 1637/9834-061611-ResNote.1.

Mavroidi, N. 2008. Transmission of zoonoses through immigration and tourism. Veterinaria Italiana 44: 651-656.

Meerburg, B.G., G.R. Singleton, and A. Kijlstra. 2009. Rodent-borne diseases and their risks for public health. Critical Reviews in Microbiology 35: 221-270. https://doi.org/10.1080/ 10408410902989837.

Mijiddorj, T.N., A. Ahearn, C. Mishra, and B. Boldgiv. 2019. Gobi Herders' decision-making and risk management under changing climate. Human Ecology 47: 785-794. https://doi.org/10.1007/ s10745-019-00112-9.

Mijiddorj, T.N., J.S. Alexander, G. Samelius, R. Badola, G.S. Rawat, and S. Dutta. 2018. Corrigendum to: Livestock depredation by large carnivores in the South Gobi, Mongolia. Wildlife Research. https://doi.org/10.1071/wr18009_co.

Mishra, C. 2000. Socioeconomic transition and wildlife conservation in the Indian trans-Himalaya. Journal of Bombay Natural History Society 97: 25-32.

Mishra, C., P. Allen, T. McCarthy, M.D. Madhusudan, A. Bayarjargal, and H.H.T. Prins. 2003a. The role of incentive programs in conserving the snow leopard. Conservation Biology 17: 1512-1520.

Mishra, C., S. Bagchi, T. Namgail, and Y.V. Bhatnagar. 2010. Multiple use of Trans-Himalayan rangelands: Reconciling human livelihoods with wildlife conservation. In Wild rangelands: Conserving wildlife while maintaining livestock in semiarid ecosystems, 1st ed., ed. J.T. du Toit, R. Kock, and J.C. Deutsch, 291-311. Oxford: Blackwell Publishing.

Mishra, C., and A. Fitzherbert. 2004. War and wildlife: A postconflict assessment of Afghanistan's Wakhan Corridor. Oryx. https://doi.org/10.1017/s0030605304000158.

Mishra, C., H.H.T. Prins, and S.E. van Wieren. 2001. Overstocking in the trans-Himalayan rangelands of India. Environmental Conservation 28: 279-283. https://doi.org/10.1017/ S0376892901000297. 
Mishra, C., H.H.T. Prins, and S.E. Van Wieren. 2003b. Diversity, risk mediation and change in a Trans-Himalayan agropastoral system. Human Ecology 31: 595-609.

Mishra, C., S.E. Van Wieren, P. Ketner, I.M.A. Heitkonig, and H.H.T. Prins. 2004. Competition between domestic livestock and wild bharal in the Indian Trans-Himalaya. Journal of Applied Ecology 41: 344-354.

Mitsouras, K., E.A. Faulhaber, G. Hui, J.O. Joslin, C. Eng, M.C. Barr, and K.J.L. Irizarry. 2011. Development of a PCR Assay to detect Papillomavirus Infection in the Snow Leopard. BMC Veterinary Research. https://doi.org/10.1186/1746-6148-7-38.

Murali, R., K. Suryawanshi, S. Redpath, H. Nagendra, and C. Mishra. 2019. Changing use of ecosystem services along a rural-urban continuum in the Indian Trans-Himalayas. Ecosystem Services. https://doi.org/10.1016/j.ecoser.2019.101030.

Namgail, T., Y.V. Bhatnagar, C. Mishra, and S. Bagchi. 2007. Pastoral Nomads of the Indian Changthang: Production system, landuse and socioeconomic changes. Human Ecology 35: 497-504. https://doi.org/10.1007/s10745-006-9107-0.

Negi, C.S., and V.S. Palyal. 2017. Traditional uses of animal and animal products in medicine and rituals by the Shoka Tribes of District Pithoragarh, Uttaranchal, India. Studies on Ethno-Medicine 1: 47-54. https://doi.org/10.1080/09735070.2007.11886300.

Nowell, K., J. Li, M. Paltsyn, and R.K. Sharma. 2016. An ounce of prevention: Snow leopard crime revisited. Cambridge: Cambridge University Press.

Olsen, B., V.J. Munster, A. Wallensten, J. Waldenström, A.D. Osterhaus, and R.A. Fouchier. 2006. Global patterns of influenza A virus in wild birds. Science 312: 384-388.

Olson, D.M., E. Dinerstein, E.D. Wikramanayake, N.D. Burgesss, G.V.N. Powell, E.C. Underwood, J.A. D'Amico, I. Itoua, et al. 2001. Terrestrial ecoregions of the world: A new map of life on earth. BioScience. https://doi.org/10.1641/00063568(2001)051[0933:Teotwa]2.0.Co;2.

Ostrowski, S., and M. Gilbert. 2016. Diseases of snow leopards and primary prey species. In Snow leopards, ed. T. McCarthy and D. Mallon, 97-112. London: Academic Press.

Ostrowski, S., F. Thiaucourt, M. Amirbekov, A. Mahmadshoev, L. Manso-Silván, V. Dupuy, D. Vahobov, O. Ziyoev et al. 2011. Fatal outbreak of Mycoplasma capricolum pneumonia in endangered markhors. Emerging Infectious Diseases 17: 2338-2341. https://doi.org/10.3201/eid1712.110187.

Otero-Abad, B., and P.R. Torgerson. 2013. A systematic review of the epidemiology of echinococcosis in domestic and wild animals. PLoS Neglected Tropical Diseases 7: e2249. https://doi.org/10. 1371/journal.pntd.0002249.

Patz, J.A., P. Daszak, G.M. Tabor, A.A. Aguirre, M. Pearl, J. Epstein, N.D. Wolfe, A.M. Kilpatrick, et al. 2004. Unhealthy landscapes: Policy recommendations on land use change and infectious disease emergence. Environmental Health Perspectives 112: 1092-1098. https://doi.org/10.1289/ehp.6877.

Pilot, M., C. Greco, B.M. von Holdt, E. Randi, W. Jedrzejewski, V.E. Sidorovich, M.K. Konopinski, E.A. Ostrander, et al. 2018. Widespread, long-term admixture between grey wolves and domestic dogs across Eurasia and its implications for the conservation status of hybrids. Evolutionary Applications 11: 662-680. https://doi.org/10.1111/eva.12595.

Prins, H.H.T., and T. Namgail. 2017. Bird migration across the Himalayas: Wetland functioning amidst mountains and glaciers. Cambridge University Press, Cambridge. https://doi.org/10. 1017/9781316335420.

Ramadan, N., and H. Shaib. 2019. Middle East respiratory syndrome coronovirus (MERS-CoV): A review. Germs 9: 35-42. https:// doi.org/10.18683/germs.2019.1155.

Randall, D.A., S.D. Williams, I.V. Kuzmin, C.E. Rupprecht, L.A. Tallents, Z. Tefera, K. Argaws, F. Shiferaw, et al. 2004. Rabies in endangered Ethiopian wolves. Emerging Infectious Diseases 10: 2214-2217.

Reed, K.D., J.K. Meece, J.S. Henkel, and S.K. Shukla. 2003. Birds, migration and emerging zoonoses: West Nile virus, lyme disease, influenza A and enteropathogens. Clinical Medicine \& Research 1: 5-12.

Roelke-Parker, M.E., L. Munson, C. Packer, R. Kock, S. Cleaveland, M. Carpenter, S.J. O'Brien, A. Pospichill, et al. 1997. A canine distemper virus endemic in serengeti lions (Panthera leo). Nature 379: 441-445.

Rohr, J.R., T.R. Raffel, A.R. Blaustein, P.T. Johnson, S.H. Paull, and S. Young. 2013. Using physiology to understand climate-driven changes in disease and their implications for conservation. Conservation Physiology 1: cot022. https://doi.org/10.1093/conphys/cot022.

Rosen, G.E., and K.F. Smith. 2010. Summarizing the evidence on the international trade in illegal wildlife. EcoHealth 7: 24-32. https://doi.org/10.1007/s10393-010-0317-y.

Saker, L., K. Lee, B. Cannito, A. Gilmore, and D.H. CampbellLendrum. 2004. Globalization and infectious diseases: A review of the linkages. Geneva: WHO.

Sariyeva, G., G. Bazarkanova, R. Maimulov, S. Abdikarimov, B. Kurmanov, A. Abdirassilova, A. Shabunin, Z. Sagiyev, et al. 2019. Marmots and Yersinia pestis strains in two plague endemic areas of Tien Shan Mountains. Frontiers in Veterinary Science 6: 207. https://doi.org/10.3389/fvets.2019.00207.

Snow Leopard Network. 2014. Snow leopard survival strategy. Seattle: Snow Leopard Trust.

Snow Leopard Working Secretariat. 2013. Global snow leopard and ecosystem protection program. Bishkek: Snow Leopard Trust.

Suryawanshi, K.R., M. Khanyari, K. Sharma, P. Lkhagvajav, and C. Mishra. 2019. Sampling bias in snow leopard population estimation studies. Population Ecology. https://doi.org/10.1002/ 1438-390x.1027.

Tiwari, P.C., A. Tiwari, and B. Joshi. 2018. Urban growth in the Himalaya: Understanding the process and options for sustainable development. Journal of Urban and Regional Studies on Contemporary India 4: 15-27.

Torgerson, P.R., B. Oguljahan, A.E. Muminov, R.R. Karaeva, O.T. Kuttubaev, M. Aminjanov, and B. Shaikenov. 2006. Present situation of cystic echinococcosis in Central Asia. International Journal for Parasitology 55 (Suppl): S207-212. https://doi.org/ 10.1016/j.parint.2005.11.032.

Turco, M., E. Palazzi, J. von Hardenberg, and A. Provenzale. 2015. Observed climate change hotspots. Geophysical Research Letters 42: 3521-3528. https://doi.org/10.1002/2015g1063891.

Victoriano, A.F., L.D. Smythe, N. Gloriani-Barzaga, L.L. Cavinta, T. Kasai, K. Limpakarnjanarat, B.L. Ong, G. Gongal, et al. 2009. Leptospirosis in the Asia Pacific region. BMC Infectious Diseases 9: 147. https://doi.org/10.1186/1471-2334-9-147.

Vittecoq, M., S. Godreuil, F. Prugnolle, P. Durand, L. Brazier, N. Renaud, A. Arnal, S. Aberkane, et al. 2016. Antimicrobial resistance in wildlife. Journal of Applied Ecology 53: 519-529. https://doi.org/10.1111/1365-2664.12596.

Walker, J.G., M. Plein, E.R. Morgan, and P.A. Vesk. 2017. Uncertain links in host-parasite networks: Lessons for parasite transmission in a multi-host system. Philosophical Transactions of the Royal Society of London B. https://doi.org/10.1098/rstb.2016.0095.

Webby, R.J., R.G. Webster, and J.A. Richt. 2007. influenza viruses in animal wildlife populations. In Wildlife and emerging zoonotic diseases: The biology, circumstances and consequences of crossspecies-transmission, ed. J.E. Childs, J.S. Mackenzie, and J.A. Rich, 67-83. Berlin: Springer.

Whitmee, S., A. Haines, C. Beyrer, F. Boltz, A.G. Capon, B.D. de Souza Dias, A. Ezeh, H. Frumkin, et al. 2015. Safeguarding human health in the Anthropocene epoch: Report of The Rockefeller Foundation-Lancet Commission on planetary health. 
The Lancet 386: 1973-2028. https://doi.org/10.1016/s01406736(15)60901-1.

WHO. 2020. Trypanosomiasis, human African (sleeping sickness. World Health Organization. https://www.who.int/en/news-room/ fact-sheets/detail/trypanosomiasis-human-african-(sleepingsickness). Accessed 10 October 2020

Wilson, M.C., and A.T. Smith. 2015. The pika and the watershed: The impact of small mammal poisoning on the ecohydrology of the Qinghai-Tibetan Plateau. Ambio 44: 16-22. https://doi.org/10. 1007/s13280-014-0568-x.

Wolfe, N.D., C.P. Dunavan, and J. Diamond. 2007. Origins of major human infectious diseases. Nature 447: 279-283. https://doi.org/ 10.1038/nature05775.

World Bank. 2020. Databank: Population esitmates and projections. https://databank.worldbank.org/source/population-estimatesand-projections. Accessed 15 November 2020

Wu, L., and H. Wang. 2017. Poisoning the pika: Must protection of grasslands be at the expense of biodiversity? Science China Life Sciences 60: 545-547. https://doi.org/10.1007/s11427-016-02220 .

Ye, Z.W., S. Yuan, K.S. Yuen, S.Y. Fung, C.P. Chan, and D.Y. Jin. 2020. Zoonotic origins of human coronaviruses. International Journal of Biological Sciences 16: 1686-1697. https://doi.org/ 10.7150/ijbs.45472.

Young, J.K., K.A. Olson, R.P. Reading, S. Amgalanbaatar, and J. Berger. 2011. Is wildlife going to the dogs? Impacts of feral and free-roaming $\operatorname{dogs}$ on wildlife populations. BioScience 61: 125-132. https://doi.org/10.1525/bio.2011.61.2.7.

Zahler, P., B. Lhagvasuren, R.P. Reading, J.R. Wingard, S. Amgalanbaatar, S. Gombobataar, N. Barton, and Y. Onon. 2004. Illegal and unsustainable wildlife hunting and trade in Mongolia. Mongolian Journal of Biological Sciences 2: 23-31. https://doi.org/10.22353/mjbs.2004.02.14.

Zhang, L., N. Hua, and S. Sun. 2008. Wildlife trade, consumption and conservation awareness in southwest China. Biodiversity Conservation 17: 1493-1516. https://doi.org/10.1007/s10531-0089358-8.

Zhou, P., X.L. Yang, X.G. Wang, B. Hu, L. Zhang, H.R. Si, Y. Zhu, et al. 2020. A pneumonia outbreak associated with a new coronavirus of probable bat origin. Nature 579: 270-273. https:// doi.org/10.1038/s41586-020-2012-7.

Ziadinov, I., A. Mathis, D. Traschel, A. Rysmukhambetova, T.A. Abdyjaparov, O.T. Kuttubaev, P. Deplazes, and P.R. Torgerson. 2008. Canine echinococcosis in Kyrgyzstan: Using prevalence data adjusted for measurement error to develop transmission dynamics models. International Journal of Parasitology 38: 1179-1190. https://doi.org/10.1016/j.ijpara.2008.01.009.

Publisher's Note Springer Nature remains neutral with regard to jurisdictional claims in published maps and institutional affiliations.

\section{AUTHOR BIOGRAPHIES}

Charudutt Mishra is Executive Director of the Snow Leopard Trust and co-founder of Nature Conservation Foundation. His research interests include ecological and social sciences and conservation conflict management.

Address: Snow Leopard Trust, 4649 Sunnyside Avenue North, Seattle, USA.

Address: Nature Conservation Foundation, 3076/5, IV Cross Gokulam Park, Mysore, India.

e-mail: charu@snowleopard.org
Gustaf Samelius is Assistant Director of Science for the Snow Leopard Trust and is working with applied ecology and conservation of snow leopards and high-mountain ecosystems.

Address: Snow Leopard Trust, 4649 Sunnyside Avenue North, Seattle, USA.

Address: Nordens Ark, Åby Säteri, 45693 Hunnebostrand, Sweden. e-mail: gustaf@snowleopard.org

Munib Khanyari is a Research Scholar at the Nature Conservation Foundation and a Ph.D. student at University of Bristol/Interdisciplinary Center for Conservation Sciences, Oxford university. His research interests lie in understanding factors affecting ungulate populations, with particular interest in trying to align people's socioeconomic needs with that of wildlife conservation.

Address: Snow Leopard Trust, 4649 Sunnyside Avenue North, Seattle, USA.

Address: Nature Conservation Foundation, 3076/5, IV Cross Gokulam Park, Mysore, India.

Address: Interdisciplinary Center for Conservation Sciences, Oxford, University, UK.

Address: Department of Biological Sciences, University of Bristol, Bristol, UK.

e-mail: munib@ncf-india.org

Prashanth Nuggehalli Srinivas is a Faculty \& DBT/Wellcome Trust India Alliance Fellow at the Institute of Public Health, Bangalore (India). His research interests include health policy and systems research, indigenous health, social determinants of health and One Health.

Address: Health Equity Cluster, Institute of Public Health, Bengaluru, India.

e-mail: prashanthns@iphindia.org

Matthew Low is an Associate Professor at the Swedish University of Agricultural Sciences. His research interests include wildlife epidemiology and population ecology.

Address: Department of Ecology, Swedish University of Agricultural Sciences, 75007 Uppsala, Sweden.

e-mail: matt.low@slu.se

Carol Esson is a Veterinarian consultant for wildlife health. Her research interests include One health research, wildlife pathology, immunology, and wildlife health and conservation.

Address: 41 Walnut Close, Speewah, Queensland 4881, Australia.

e-mail: cesson@aapt.net.au

Suri Venkatachalam is an Adjunct faculty at the Nature Conservation Foundation. His research interest includes ecological history.

Address: Snow Leopard Trust, 4649 Sunnyside Avenue North, Seattle, USA.

Address: Nature Conservation Foundation, 3076/5, IV Cross Gokulam Park, Mysore, India.

e-mail: suri.venkatachalam@ncf-india.org

Örjan Johansson $(\square)$ is a Researcher at the Swedish University of Agricultural Sciences and Snow Leopard Trust. His research interests include large carnivore ecology and conservation.

Address: Snow Leopard Trust, 4649 Sunnyside Avenue North, Seattle, USA.

Address: Department of Ecology, Grimsö Wildlife Research Station, Swedish University of Agricultural Sciences, 73091 Riddarhyttan, Sweden.

e-mail: orjan.johansson@slu.se 